\title{
Optimalisasi Fungsi Manajemen Dalam Meningkatkan Peran Dan Fungsi Masjid
}

\author{
Mochamad Rifqi Taufiq $\mathbf{H}^{1^{*}}$ \\ ${ }^{1}$ Jurusan Manajemen Dakwah Fakultas Dakwah dan Komunikasi \\ UIN Sunan Gunung Djati Bandung \\ *Email: Mochamadrifqi99@gmail.com1
}

\begin{abstract}
ABSTRAK
Masjid memang mesti berkembang dinamis, ia tidak semestinya dibiarkan tanpa upaya perbaikan dan penyempurnaan. Inovasi tanpa henti selalu dibutuhkan agar masjid dapat senantiasa selaras dengan perkembangan zaman dan karenanya, tidak ditinggalkan umat.. Penelitian ini dilakukan bertujuan untuk mengetahui optimalisasi fungsi-fungsi manajemen (planning, organizing, actuating, controlling) yang diterapkan oleh pengurus Masjid Istiqamah dalam sebuah organisasi kelembagaan serta melakukan berbagai kegiatan guna meningkatkan peran dan fungsi masjid. Manajemen masjid secara garis besar terbagi menjadi dua bidang; pertama, physical management dan kedua, functional management. Metode yang digunakan dalam penelitian ini adalah menggunakan metode deskriptif, melalui pendekatan kualitatif. Peneliti terlibat langsung melakukan penelitian di lokasi Masjid Istiqamah. Teknik penelitian yang ditempuh oleh peneliti untuk memperoleh data yang dibutuhkan dengan cara; observasi, wawancara, dan dokumentasi. Dengan demikian dapat disimpulkan bahwa penerapan fungsi manajemen pada Masjid Istiqamah, yakni: Penerapan fungsi perencanaan pada setiap kegiatan dan program yang meliputi peramalan, penentuan sasaran, penjadwalan, pengganggaran dan penentuan prosedur kerja; Penerapan fungsi pengorganisasian yang meliputi pengorganisasian alat, pengelompokan kerja, penentuan dan pelimpahan tanggung jawab dan wewenang; Penerapan fungsi penggerakan pada Masjid Istiqamah yang meliputi pimpinan memberikan motivasi dan mengkoordinasi; Penerapan fungsi pengendalian yang meliputi pemimpin melakukan penilaian dan evaluasi pada setiap kegiatan maupun kepengurusan.
\end{abstract}

Kata Kunci: Optimalisasi; Fungsi Manajemen; Masjid 


\section{ABSTRACT}

Mosques must indeed develop dynamically, they should not be left without efforts to repair and perfect. Continuous innovation is always needed so that the mosque can always be in tune with the times and therefore, the people are not left behind. This research was conducted to determine the optimization of management functions (planning, organizing, actuating, controlling) implemented by Istiqamah Mosque administrators in an organization. institutions and carry out various activities to improve the role and function of the mosque Mosque management is broadly divided into two areas; first, physical management and second, functional management. The method used in this research is descriptive method, through a qualitative approach. Researchers were directly involved in conducting research at the Istiqamah Mosque location. Research techniques used by researchers to obtain the required data by means of; observation, interview, and documentation. Thus it can be concluded that the implementation of management functions at the Istiqamah Mosque, namely: Implementation of planning functions in every activity and program which includes forecasting, targeting, scheduling, budgeting and determining work procedures; Implementation of the organizational function which includes organizing tools, grouping work, determining and delegating responsibilities and authorities; The implementation of the movement function at the Istiqamah Mosque which includes the leadership to provide motivation and coordination; The implementation of the control function, which includes the leader evaluating and evaluating each activity and management.

Keywords: Optimization; Management Function; Mosque

\section{PENDAHULUAN}

Masjid yang dibangun dalam bentuk yang paling sederhana maupun yang sangat mewah, tidak akan berdaya-guna secara optimal apabila pengelolaan dan kepengurusannya tidak berjalan dengan baik. Karena setiap organisasi maupun kelembagaan sangat ditunutut pengelolaan yang efektif, efesien dan produktif. Oleh karenanya, proses manajerial harus menjadi perhatian utama pada sebuah masjid. Untuk mewujudkan situasi yang demikian, perlu peningkatan kesadaran tentang maksud dari semua kegiatan manajemen masjid, yaitu untuk meningkatkan sumber daya manusia terhadap keberhasilan organisasional.Dengan katalain, bahwa kebijaksanaan apapun yang diterapkan dan dirumuskan dalam peningkatan peran dan fungsi masjid dan langkah-langkah apapun yang diambil dalam manajemen masjid, semuanya harus berkaitan dengan pencapaian berbagai jenis tujuan yang telah ditetapkan bersama untuk dicapai.

Dalam penelitian ini peneliti mencoba mengedepankan fungsi-fungsi manajemen. Aspek-aspek manajemen yang digunakan tidak hanya berpedoman pada standar-standar tekhnis belaka, tetapi juga berpedoman pada aturan-aturan atau nilai-nilai agama.Dengan demikian hal ini mensinergikan antara aspek duniawi (teknis, perencanaan, pengorganisasian, pengaplikasian, pengawasan), dengan 
aspek ukhrawi (fungsi masjid dan nilai-nilai Al-Qur'an). Ketidak-seimbangan antara keduanya akan menciptakan kemadaratan, masjid yang mubazir karena tidak ada yang menggunakan atau kurang termanfaatkan, pembangunan masjid yang berlebih-lebihan dan bermegah-megahan tanpa adanya proses manajemen masjid yang baik dan masjid yang mengabaikan aturan serta nilai-nilai agama.

Masjid Istiqamah termasuk salah satu masjid megah yang ada di Kota Bandung.Menurut pengamatan penulis, masjid yang melayani tidak hanya kebutuhan spiritual yang berhubungan dengan Allah, tapi juga masjid yang peduli pada pendidikan, ekonomi dan sosial masyarakat sekelilingnya. Pendirian Masjid Istiqamah yang tak bisa dilepaskan dari sosok dua orang 'ulama besar, yakni Alm. KH EZ Muttaqien dan Alm. KH Rusyad Nurdin. Di masa hidupnya kiprah kedua tokoh ini tak hanya dikenal di lokal Bandung saja, namun juga di tingkat nasional.Alm.KH EZ Muttaqien pernah menjadi ketua Majelis Ulama Indonesia (MUI), sedangkan KH.Rusyad Nurdin dikenal sebagai tokoh Masyumi dan Dewan Dakwah Islamiyah Indonesia (DDII).

Sebelum menempati lokasi yang sekarang, masjid yang lokasinya juga dekat dengan Gedung Sate ini awalnya hanyalah sebuah masjid kecil di pasar Cihapit Bandung. Di era 60-an masjid tersebut dipindahkan ke lokasi di sekitar Taman Citarum. Kemudian di sekitar tahun 1968 mulailah berdiri Yayasan Istiqamah yang salah satu fungsinya mengelola dan memakmurkan masjid.Masjid yang pada mulanya hanya sebagai masjid biasa saja menjadi kian berkembang, secara fungsi dan peranannya bahkan menyentuh ke berbagai bidang sosial lainnya. Namun untuk mengembalikan peran dan fungsi masjid secara utuh tidaklah mudah, pamor masjid harus bersaing dengan institusi mapan dan kuatnya pemahaman fiqhiyah bahwa masjid hanya sebagai tempat shalat saja, ditambah dengan adanya problem klasik bagi masjid, yaitu minim atau tiadanya dana pengembangan.

Manejerial yang baik adalah kunci untuk mengembalikan masjid pada peran dan fungsi yang sebenarnya. Lokasi penelitian penulis di Masjid Istiqamah Jl. Taman Citarum Bandung 40117.

Bagaimana proses perencanaan (planning) yang dilakukan oleh Masjid Istiqamah dalam meningkatkan peran dan fungsi masjid?

Bagaimana proses pengorganisasian (organizing) yang dilakukan oleh Masjid Istiqamah dalam meningkatkan peran dan fungsi masjid?

Bagaimana proses pelaksanaan (actuating) yang dilakukan oleh Masjid Istiqamah dalam meningkatkan peran dan fungsi masjid?

Bagaimana pengawasan yang diterapkan dalam melakukan proses pengawasan (controlling) dalam meningkatkan peran dan fungsi masjid?

Penulis menggunakan metode deskriptif, melalui pendekatan kualitatif. Disebut demikian karena sesuai dengan tujuan penelitiannya yaitu melukiskan secara sistematis dan cermat.Oleh karena itu tidak mencari atau menjelaskan 
hubungan, tidak pula menguji hipotesis atau membuat prediksi, melainkan lebih menitikberatkan pada observasi dan suasana alamiah. Selanjutnya dalam proses keberlangsungannya peneliti terlibat langsung melakukan observasi penelitian di Masjid Istiqamah. 1) Observasi, teknik ini ditempuh penulis dengan cara melakukan pengamatan dan pencatatan terhadap permasalahan yang secara langsung penulis lihat dari situasi dan kondisi sebenarnya di Masjid Istiqamah Bandung. 2) Wawancara, melalui kegiatan wawancara ini peneliti sebagai pewawancara memancing pembicara dari pengurus Masjid Istiqamah dan pihakpihakyang terkait dengan kebutuhan penelitian. Pada prosesnya peneliti berupaya menggiring pembicaraan secara sistematis guna mengetahui segala hal yang berhubungan dengan rumusan masalah penelitian. 3) Dokumentasi, data ini diperoleh melalui pengumpulan dokumentasi dari obyek yang diteliti dengan masalah yang ada. Pada teknisnya penulis meminta bantuan kepada pihak Masjid Istiqamah untuk memberikan data dokumentasi yang dibutuhkan dalam penelitian ini. Data yang dimaksud berupa arsip-arsip manjerial Masjid Istiqamah dan lain sebagainya.

Proses penelitian ini dilaksanakan secara terus menerus sejak awal penelitian hingga akhir, sehingga melahirkan induktif permasalahan yang diteliti dan kemudian proses pencarian atau penyesuaian pola, model, tema, sampai pada teori yang dirumuskan secara keseluruhan. Seleksi data yang telah terkumpul, klasifikasi data berdasarkan kategori tertentu yang menunjang masalah penelitian, mencari hubungan antara data yang sudah diklasifikasikan dengan teori ideal tentang penerapan fungsi manajemen terhadap peningkatan peran masjid, menafsirkan data yang telah dihubungkan antara masalah dengan teori yang ada, penarikan kesimpulan yang didasarkan pada hasil analisis.

\section{LANDASAN TEORI}

Pada dasarnya kemampuan manusia itu terbatas (fisik, pengetahuan, waktu, dan perhatian) sedangkan kebutuhannya tidak terbatas.Usaha untuk memenuhi kebutuhan dan terbatasnya kemampuan dalam melakukan pekerjaan mendorong manusia membagi pekerjaan, tugas, dan tanggung jawab.Dengan adanya pembagian kerja, tugas, dan tanggung jawab ini maka terbentuklah kerja-sama dan keterikatan formal dalam suatu organisasi. Dalam organisasi ini maka pekerjaan yang berat dan sulit akan dapat diselesaikan dengan baik serta tujuan yang diinginkan tercapai (Hasibuan, 2006:3).

Dewasa ini umat Islam terus menerus mengupayakan pembangunan masjid.Bermunculan masjid-masjid baru diberbagai daerah di Indonesia.Disamping renovasi atas masjid-masjid lama.Setelah bangunan fisik masjid berdiri, volume kegiatan yang berlangsung didalamnya juga beragam ada 
yang mampu mengintensifkan kegiatannya seharian penuh dengan menyelenggarakan tingkat pendidikan rendah sampai tingkat tinggi Sebaliknya tidak sedikit jumlah masjid yang pembangunannya sangat diusahakan, justru minim dari kegiatan.

Permasalahan tersebut terkait dengan pengurus atau takmir yang yang kurang proaktif dalam merencanakankemakmuran masjid.Ketika masjid hanya digunakan untuk melaksanakan ibadah mahdoh seperti shalat dan sejenisnya, maka tidak banyak orang yang terlibat atau dilibatkan dalam kepengurusan, apalagi memang banyak masjid yang tidak memiliki struktur kepengurusan yang memadai. Dengan memaksimalkan fungsi-fungsi manajemen atau pengelolaan, masjid tentunya akan lebih berdaya dan tidak akan muncul ke permukaan dengan citra yang memprihatinkan, sesuatu yang penuh dengan kemiskinan dan keterlantaran sebab keberdayaan sebuah masjid berhubungan dengan keberdayaan masyarakat yang ada di sekitarnya. Masjid akan menjadi lebih mandiri jika dikelola secara lebih professional serta sistematis sehingga mampu mengurangi penderitaan masjid itu sendiri di satu sisi dan memberdayakan masyarakat umum di sisi lain (Rifa'i \& Fakhruroji 2005:14).

Agar pengelola masjid dapat bekerja dengan baik, maka dalam menjalankan roda kepengurusan, diperlukan mekanisme kerja yang baik.Untuk itu, manajemen masjid sangatlah penting untuk diterapkan.Peran dan fungsi masjid semakin berkembang dari masa ke masa, baik secara fungsional sebagai tempat ibadah, maupun secara eksistensial sebagai lembaga dan pranata sosial Islam. Dari bangunan yang bernama masjidlah kemudian bermunculan ribuan universitas dan pusat-pusat kajian Islam yang padat dikunjungi oleh penduduk dari seluruh penjuru dunia (Rifa’i \& Fakhruroji 2005:4), selain dijadikan untuk tempat ibadah shalat, masjid juga kemudian digunakan sebagai sentral kegiatan sosial, seperti pendidikan, seni-budaya, hukum, politik, ekonomi, dan sebagainya.

Apapun faktanya, masjid memang mesti berkembang dinamis. Ia tidak semestinya dibiarkan tanpa upaya perbaikan dan penyempurnaan. Inovasi tanpa henti selalu dibutuhkan agar masjid dapat senantiasa selaras dengan perkembangan zaman dan karenanya, tidak ditinggalkan umat.Sebagai sebuah lembaga dan organisasi, masjid dituntut untuk memiliki manajerial yang baik dan daya pikat kuat terhadap umatnya.Daya pikat inilah yang sepanjang sejarah masjid menjadi semacam amunisi bagi peningkatan peran dan fungsi masjid.

Dalam memakmurkan atau mengembalikan fungsi dan peranan masjid sudah seharusnya diimbangi dengan kesadaran dan ditunjang dengan potensi dalam mengelolanya. Dalam proses pengelolaan kita perlu memperhatikan ilmu manajemen. Dalam Al-Qur'an surat Ash-Shaff ayat 4: 


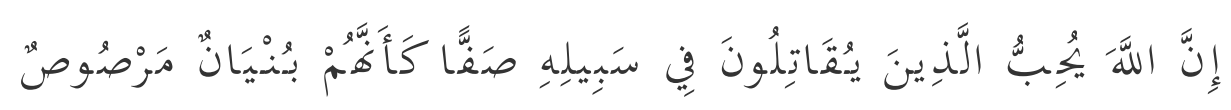

"Sesunggubnya Allab menyukai orang yang berperang dijalan-Nya dalam barisan yang teratur seakan-akan mereka seperti suatu bangunan yang tersusun kokoh." (Kemenag RI 2009:551).

Secara eksplisit, ayat tersebut mengajarkan semua kaum muslimin untuk mengamalkan ilmu manajemen dalam setiap pekerjaan, karena Islam menghendaki dalam mengatur segala sesuatu agar dilakukan dengan baik, tepat, terencana dan tuntas guna tercapainya tujuan yang diinginkan.

Sedangkan menurut George R. Terry (dalam Hasibuan 2006:2), " management is a distinct process of planning, organizing, actuating and controlling, perform to determine and accomplish stated objectives by the use of human beings and other resources." (Manajemen ialah proses yang khas terdiri dari perencanaan, pengorganisasian, pelaksanaan dan pengawasan yang dilakukan untuk menentukan dan mencapai tujuan yang telah ditetapkan dengan menggunakan tenaga dan sumber daya lainnya.)

\section{HASIL DAN PEMBAHASAN}

Dari data yang penulis dapatkan dari lapangan untuk menganalisis optimalisasi fungsi manajemen pada Masjid Istiqamah dalam meningkatkan peran dan fungsi masjid, penulis akan melihat atau memfokuskan pada program kegiatan yang dilakukan Masjid Istiqamah dalam meningkstksn peran dan fungsi masjid.

Masjid Istiqamah termasuk salah satu masjid megah yang ada di Kota Bandung. Menurut pengamatan penulis, masjid yang melayani tidak hanya kebutuhan spiritual yang berhubungan dengan Allah, tapi juga masjid yang peduli pada kesejahteraan ekonomi dan sosial masyarakat sekelilingnya. Pendirian Masjid Istiqamah yang tak bisa dilepaskan dari sosok dua orang 'ulama besar, yakni Alm. KH EZ Muttaqien dan Alm. KH Rusyad Nurdin. kiprah kedua tokoh ini tak hanya dikenal di lokal Bandung saja, namun juga di tingkat nasional. Alm.KH EZ Muttaqien pernah menjadi ketua Majelis Ulama Indonesia (MUI), sedangkan KH. Rusyad Nurdin dikenal sebagai tokoh Masyumi dan Dewan Dakwah Islamiyah Indonesia (DDII).

Masjid Istiqamah tidak berada di bawah kekuatan suatu ormas atau orpol tertentu, semua yang duduk dalam kepengurusan tidak mewakili suatu organisasi manapun, tetapi duduk berdampingan secara collegial. Sebelum menempati lokasi yang sekarang, masjid yang lokasinya juga dekat dengan Gedung Sate ini awalnya hanyalah sebuah masjid kecil di pasar Cihapit Bandung. Di era 60-an masjid tersebut dipindahkan ke lokasi di sekitar Taman Citarum. Mengenai tokoh yang 
terlibat dalam pembangunan Masjid Istiqamah Cihapit yakni, Ronodikromo dan istrinya Sumirah sebagai perintis. Setelah Ronodikromo wafat diteruskan oleh Sukatma. Pembangunannya dilaksanakan oleh mantu-mantunya yaitu, Witarmudi, Hamdan, dan Mahmudin semua sudah wafat. Terakhir muncul seorang dermawan H. Oemar Mansur pengusaha penerbitan, kemudian (May) U. Zaenal Abidin, Kapten Harun, Suyono dan lain-lain.

Mengenai pembangunan Masjid Istiqamah Taman Citarum ada dua alasan, yaitu, pertama, baik luas tanah maupun lokasi masjid Istiqamah Cihapit kurang memungkinkan untuk dikembangkan lebih jauh. Kedua, tuntutan situasi setelah terjadi gerakan 30 September 1965/PKI peran masjid dalam upaya pembinaan mental bangsa. Sementara itu meningkatkan kualitas kehidupan beragama menjadi sangat penting. Kemudian di sekitar tahun 1968 mulailah berdiri Yayasan Istiqamah yang salah satu fungsinya mengelola dan memakmurkan masjid. Masjid yang pada mulanya hanya sebagai masjid biasa saja menjadi kian berkembang, secara fungsi dan peranannya. Diawali dengan pendirian Taman Kanak-kanak (TK) di pertengahan dekade 80-an, lalu Sekolah Dasar (SD) pada 1992, dan SLTP lima tahun kemudian. bahkan sampai hari ini perkembangan peran dan fungsinya terus mengalami peningkatan.

Adapun program kegiatan di Masjid Istiqamah yang awalnya hanya digunakan untuk melaksanakan ibadah sholat, namun seiring dengan berjalannya waktu mulai ikut berperan dalam kegiatan-kegiatan lainnya. Diantaranya adalah menyelenggarakan seminar, dialog, pelatihan baik dilaksanakan oleh lembagalembaga internal masjid maupun dari pihak-pihak luar.Ditambah lagi dengan fasilitas maupun pelayanan yang diberikan oleh masjid, seperti fasilitas penyewaan ruangan yang dapatdipakai untuk pernikahan maupun penyelenggaraan kegiatan seperti di atas. Terdapat juga layanan bimbingan Haji \& Umrah, konsultasi keagamaan, baik untuk orang dewasa maupun remaja, layanan untuk zakat harta, fitrah maupun qurban, pengurusan jenazah, ataupun ceramah rutin dan pelatihanpelatihan dakwah, yang mana kegiatan tersebut dapat membantu masyarakat sekitar masjid (wawancara dengan H. Nana Sudjana sebagai Ketua Bidang Kemasjidan dan Dakwah pada tanggal 12 Agustus 2016).

Masjid adalah milik umat dan bukan milik kelompok atau golongan tertentu, masjid harus digunakan sebagai sarana untuk memperkokoh persatuan dan persaudaraan masyarakat, membina ukhuwab Islamiyah yang sebenar-benarnya. Begitu salah tempat apabila masjid digunakan untuk memecah-belah persatuan dan persaudaraan diantara umat Islam. Peranan masjid sebagai tempat pengarahan dan penerangan, baik yang menyangkut masalah sosial keagamaan maupun sosial kemasyarakatn harus lebih efektif dan seimbang sehingga peningkatan kesadaran beragama dan kesadaran sosial dapat berjalan secara harmonis, dan pada gilirannya akan tercipta pula suatu komunitas umat yang taat beragama. Kendatipun 
demikian, masjid harus tetap mencerminkan tempat suci yang anggun dan berwibawa, sehingga orang dapat melaksanakan ibadah dengan khusyu' dan menyenangkan (Rifa'i \& Fakhruroji 2005:36).

Ketika Rasulullah berhijrah ke Madinah, langkah pertama yang beliaulakukan adalah membangun masjid kecil yang berlantaikan tanah, danberatapkan pelepah kurma. Dari sana beliau membangun masjid yang besar,membangun dunia ini, sehingga kota tempat beliau membangun itu benarbenarmenjadi Madinah, (seperti namanya) yang arti harfiahnya adalah tempat peradaban, atau paling tidak, dari tempat tersebut lahir benih peradaban baru umat manusia.

Masjid pertama yang dibangun oleh Rasulullah Saw. Adalah Masjid Quba', kemudian disusul dengan Masjid Nabawi di Madinah. Terlepas dari perbedaan pendapat 'ulama tentang masjid yang dijuluki Allah sebagai masjid yang dibangun atas dasar takwa, yang jelas bahwa keduanya, Masjid Quba dan Masjid Nabawi dibangun atas dasar ketakwaan, dan setiap masjid seharusnya memiliki landasan dan fungsi seperti itu. Itulah sebabnya mengapa Rasulullah Saw meruntuhkan bangunan kaum munafik yang juga mereka sebut masjid, dan menjadikan lokasi itu tempat pembuangan sampah dan bangkai binatang, karena di bangunan tersebut tidak dijalankan fungsi masjid yang sebenarnya, yakni ketakwaan.

Manifestasi pemerintahan terlaksana didalam Masjid, baik pada pribadipribadi pemimpin pemerintahan yang menjadi imam atau khatib maupun di dalam ruanganruangan masjid yang dijadikan tempat-tempat kegiatan pemerintahan dan syura (musyawarah). Keadaan itu kini telah berubah, sehingga timbulah lembagalembaga baru yang mengambil alih sebagian peranan masjid dimasa lalu, yaitu organisasi-organisasi keagamaan swasta dan lembaga-lembaga pemerintah, sebagai pengarah kehidupan duniawi dan ukhrawi umat beragama. Lembaga-lembaga itu memiliki kemampuan material dan teknis melebihi masjid.

Fungsi dan peranan Masjid besar seperti yang disebutkan pada masa keemasan Islam itu tentunya sulit diwujudkan pada masa kini. Namun, ini tidak berarti bahwa Masjid tidak dapat berperan didalam hal-hal tersebut. Masjid, khususnya Masjid besar, harus mampu melakukan kesepuluh peran tadi. Paling tidak melalui uraian para pembinanya guna mengarahkan umatpada kehidupan duniawi dan ukhrawi yang lebih berkualitas. Apabila Masjid dituntut berfungsi membina umat, tentu sarana yang dimilikinya harus tepat, menyenangkan dan menarik semua umat, baik dewasa, anak-anak, tua, muda, pria, wanita, yang terpelajar maupun tidak, sehat atau sakit, serta kaya dan miskin (Mustofa, 2007 : 26).

Fungsi utama Masjid adalah tempat sujud kepada Allah SWT, tempat sholatdan tempat beribadat kepadanya. Lima kali sehari semalam umat Islam dianjurkanmengunjungi masjid guna melaksanakan shalat berjama’ah. Masjid juga 
tempat yangpaling banyak di kumandangkan nama Allah melalui, azan, iqomat, tasbih, tahmid,tahlil, istighfar dan ucapan lain yang dianjurkan dibaca di Masjid sebagai bagian dari lafadz yang berkaitan dengan pengagungan asma' Allah.

Berbicara mengenai fungsi masjid dalam lingkungan masyarakat Islam, kita akan menemukan beberapa fungsi yang dapat dikategorikan menjadi dua jenis, yakni primer dan sekunder. Penyebutan istilah primer dan sekunder sama sekali tidak bermaksud untuk membuat dikotomi terhadap fungsi masjid itu sendiri. Fungsi primer yang dimaksud ialah sebagai tempat ibadah yang bersifat ritual; seperti shalat, i'tikaf, dan sebagainya. Sedangkan yang bersifat sekunder ialah segala kegiatan yang memiliki dimensi muamalah yang berkenaan dengan hubungan sesama anggota masyarakat yang ada disekitar lingkungan masjid tersebut yang secara substansial sesungguhnya masih merupakan bentuk ibadah juga. Oleh sebab itu secara menyeluruh, kedua kategori ini saling melengkapi dan oleh karenanya keduanya merupakan fungsi yang terintegrasi dan bersifat komplementer.

Namun demikian, secara umum baik secara primer maupun sekunder paling tidak masjid memiliki beberapa fungsi-fungsi berikut: Sebagai tempat shalat; Fungsi sosial kemasyarakatan; Fungsi politik; Fungsi pendidikan; Fungsi ekonomi; dan Fungsi pengembangan seni dan budaya.

Keenam fungsi masjid tersebut sekaligus merupakan fakta bahwa masjid merupakan pranata sosial dalam masyarakat Islam yang memiliki peran sebagai wahana ekspresi dan pemenuhan kebutuhan masyarakat yang mendasar. Melalui masjid, setiap anggota masyarakat Islam mencurahkan sumber daya yang dimilikinya untuk kemakmuran masjid tersebut (Rifa’i \& Fakhruroji 2005:45-46).

Selanjutnya salah satu aktivitas keagamaan yang secara langsung digunakan untuk mensosialisasikan ajaran Islam bagi penganutnya dan umat manusia pada umumnya adalah aktivitas dakwah. Aktivitas ini dilakukan baik melalui lisan, tulisan, maupun perbuatan nyata. Secara kualitatif dakwah Islam bertujuan untuk mempengaruhi dan mentransformasikan sikap batin dan perilaku warga masyarakat menuju suatu tatanan keshalehan individu dan keshalehan sosial. Dakwah dengan pesan-pesan keagamaan dan pesan-pesan sosialnya juga merupakan ajakan kepada kesadaran untuk senantiasa memiliki komitmen (istiqamah) di jalan yang lurus. Dakwah adalah ajakan yang dilakukan untuk membebaskan individu dan masyarakat dari pengaruh eksternal nilai-nilai syaithaniah dan kejahiliahan menuju internalisasi nilai-nilai ketuhanan (Munir \&Ilaihi 2006:1-2).

Berdasarkan uraian penulis maka, yang dimaksud kegiatan dakwah dalam penelitian skripsi ini adalah suatu aktifitas yang berisi ajakan atau seruan yangdilakukan oleh pengelola atau takmir Masjid Istiqamah dalam melaksanakan kegiatan dakwah. Kegiatan ini diantaranya adalah penyelenggaraan shalat jama'ah, 
ceramah keagamaan, pengajian rutin, penyelenggaraan pendidikan sekolah, pelaksanaan seminar, dialog, pelatihan baik dilaksanakan oleh lembaga-lembaga internal masjid maupun dari pihak-pihak luar, layanan bimbingan Haji \& Umrah, konsultasi keagamaan, baik untuk orang dewasa maupun remaja, layanan untuk zakat harta, fitrah maupun qurban.

Dalam manajemen masjid secara garis besar menurut Ayub (1996:33) terbagi menjadi dua bidang; pertama, physical management (idarah bina al madiy, manajemen fisik), kedua, functional management (idarab bina'al rubani, manajemen fungsional). Physical management atau manajemen fisik adalah manajemen yang meliputi kepengurusan masjid, pemeliharaan tata tertib, pengaturan keuangan, administrasi masjid, dan pemeliharaan tempat-tempat di sekitar masjid. Sementara Functional management adalah pengaturan tentang pelaksanaan fungsi masjid sebagai wadah Pembina umat, pusat pembangunan umat dan kebudayaan Islam, termasuk di dalamnya pendidikan dan pembinaan akidah dan akhlak mulia.

Termasuk ke dalam unsur manajemen fisik adalah pengorganisasian secara lengkap dan struktur masjid. Supardi (2001:25) megatakan bahwa, setidaknya ada empat unsur penting dalam sebuah organisasi masjid; Imam masjid (dewan suriah); Manajer atau ketua DKM; Tata usaha (sekretaris dan bendahara); Operasional (bidang-bidang).

Dewan suriyah yang dalam hal ini bisa merupakan orang-orang yang biasa dijadikan imam masjid memiliki wewenang untuk melakukan berbagai tindakan efekif yang diperlukan oleh jama'ah atau umat. Dalam prakteknya, ia tidak dapat bekerja secara sendiri, ia memiliki sekretaris yang bertugas untuk mengarsipkan dokumen-dokumen surat, mempersiapkan dokumen yang diperlukan dan bersama-sama dalam mengambil keputusan. Demikian juga dengan seorang bendahara. Ia adalah orang yang diserahi tanggung jawab untuk mengurusi masalah jeuangan masjid. Laporan-laporan keuangan dibuat secara berkala atau setelah kegiatan-kegiatan tertentu. Dalam tataran operasional, kegiatan masjid tidak hanya dilakukan oleh orang-orang dengan jabatan di atas, tetapi juga didukung dengan para pelaksana baik yang bersifat sementara maupun permanen (Rifa'i \& Fakhruroji 2005:108-109).

Administrasi adalah mengurus, menuntun, atau mengendalikan organisasi kearah tujuan untuk mewujudkan tujuan. Namun dalam pengertian yang lebih luas, administrasi adalah keseluruhan proses kerjasama antara dua orang atau lebih yang didasarkan atas rasionalitas tertentu untuk mencapai tujuan yang telah ditentukan sebelumnya.Sebagai kegiatan yang terangkai dalam sebuah sistem dan mekanisme organisasi, ia merupakan kegiatan yang tiada henti sepanjang organisasi masih ada dan berkembang memberikan pelayanan kepada masyarakat (Rifa'i \& Fakhruroji 2005:110-111). Beberapa contoh penerapan administrasi dalam kegiatan pengelolaan masjid ialah sebagai berikut: Pengurus menentukan 
jadwal imam dan khatib untuk shalat jum'at yang diinformasikan kepada masingmasing imam maupun khatib jauh-jauh hari sebelumnya. Jika telah mendapat kepastian, pengurus menuliskannya dalam papan informasi yang biasa dipasang di salah satu bagian masjid sehingga semua jama'ah dapat mengetahuinya; Pengurus melakukan penentuan jadwal pengajian dan ceramah dalam hal waktu, tema, dan penceramah yang bersangkutan; Membuat laporan mengenai pekembangan masjid secara berkala. Informasi yang disajikan antara lain mengenai; keadaan benda-benda inventaris, berbagai kegiatan yang telah dilaksanakan, rencanarencana kegiatan.

Struktur organisasi merupakan salah satu acuan umum bagi organisasi untuk memahami masing-masing tugas di setiap lini. Penjelasan dan pembagian kerja merupakan upaya yang dilakukan untuk membuat garis pedoman yang jelas dan dipahami secara merata, sehingga masing-masing lini bertanggung jawab terhadap tugas dan wewenang masing-masing. Untuk membantu lancarnya manajemen organisasi masjid mesti ditunjang oleh tertibnya kegiatan administrasi. Administrasi bisa merupakan cerminan berjalan atau tidaknya sebuah roda organisasi.

Program-program kegiatan dakwah Masjid Istiqamah tersebut akan penulis kaitkan dengan fungsi manajemen untuk menganalisis bagaimana manajemen takmir Masjid Istiqamah dalam melaksanakan kegiatan tersebut.

\section{Planning}

Perencanaan yang diterapkan oleh Masjid Istiqamah cukup efektif dan efesien karena dalam rangka melaksanakan program kerja sebelumnya para pengurusatau takmir telah menyusun dan merencanakan langkah-langkah yang akan dilakukan, hal ini dilaksanakan dalam rangka pencapaian tujuan dan juga usaha pemakmuran masjid. Adapun langkah-langkah yang dilakukan oleh Masjid Istiqamah pada setiap kegiatan yang terkait dengan manajemen perencanaan takmir masjid adalah: merencanakan kegiatan dakwah, dengan mengadakan kegiatan keagaman, menyelenggarakan seminar, dialog keagamaan, pelatihan haji dan umroh baik dilaksanakan oleh lembaga-lembaga internal masjid maupun dari pihak-pihak luar, menentukan target/out put dari kegiatan, serta memperhitungkan estimasi dana pada rapat internal pengurus masjid dan disampaikan pada rapat awal tahun dengan seluruh pengurus yayasan (wawancara dengan H. Nana Sudjana sebagai Ketua Bidang Kemasjidan dan Dakwah pada tanggal 12 Agustus 2016).

Sedangkan perencanaan dalam manajemen masjid itu sendiri merupakan suatuusaha untuk menetapkan rencana kegiatan yang akan dilaksanakan dan program itu dirumuskan terlebih dahulu sebelum memasuki tahap perencanaan. Setiap usaha atau kegiatan apapun tujuannya, hanya dapat berjalan secara efektif 
dan efesien apabila sebelumnya sudah dipersiapkan dan direncanakan sebelumnya secara matang. Dalam manajemen masjid perencanaan itu sendiri adalah perumusan tentang apa yang akan dilakukan dalam mencapai tujuan pemakmuran masjid, sesuai dengan tingkat kemampuan yang dimiliki. Sebelum program dilaksanakan, pihak pengurus Masjid Istiqamah sebelumnya telah mengadakan penyusunan panitia kerja, penentuan dan perumusan rencana-rencana kerja yang akan dilaksanakan, menetapkan metode, menetapkan penggalangan dana serta penetapan dan penjadwalan waktu kegiatan (wawancara dengan H. Nana Sudjana sebagai Ketua Bidang Kemasjidan dan Dakwah pada tanggal 12 Agustus 2016).

Menurut pengamatan penulis perencanaan memiliki arti yang sangat penting bagi Masjid Istiqamah.Pertama, aktivitas pemakmuran masjid bisa lebih bejalan dengan terarah dan teratur.Kedua,memungkinkan dipilihnya tindakan-tindakan yang tepat sesuai dengan situasi dankondisi yang dihadapi pada saat upaya pemakmuran masjid dlaksanakan. Ketiga, dapat dipersiapkan terlebih dahulu tenaga-tenaga pelaksana dalam memakmurkan masjid,begitu juga dengan dana dan sarananya. Dan keempat, perencanaan juga akan memudahkan pimpinan pengurus masjid untuk melaksanakan pengawasan dan penilaian terhadap jalannya aktivitas pemakmuran masjid. Dari pedoman tersebut Masjid Istiqamah menampakkan eksistensinya untuk lebih meningkatkan keimanan masyarakat dengan kegiatan-kegiatan yang ada di dalammnya.

Menurut analisa penulis, setelah mengamati dan melakukuan wawancara dengan Ketua Bidang Kemasjidan dan Dakwah di Masjid Istiqamah, bahwa takmir Masjid Istiqamah telah melalui beberapa tahapan perencanaan yang baik, 1) Menetapkan tujuan perencanaan, dimulai dengan keputusan-keputusan tentang keinginan atau kebutuhan organisasi. Dengan kejelasan tersebut akan mempermudah dalam sumber daya secara efektif. 2) Merumuskan keadaan saat ini. Dengan menganalisa keadaan saat ini.Rencana dapat dirumuskan untuk menggambarkan rencana kegiatan lebih lanjut. 3) Mengidentifikasi segala kemudahan dan hambatan. Segala kekuatan dan kelemahan perlu diidentifikasi untuk mengukur kemampuan organisasi dalam mencapai tujuan.Oleh karena itu perlu diketahui faktor-faktor lingkungan intern dan ekstern yang dapat membantu dalam pencapaian tujuan. 4) Mengembangkan rencana atau serangkaian kegiatan untuk mencapai tujuan. Tahap terakhir dalam proses perencanaan meliputi pengembangan berbagai alternative kegiatan untuk pencapaian tujuan.

Tahapan-tahapan tersebut dilakukan pada saat rapat dengan seluruh pengurus Yayasan Istiqamah dan pada rapat internal kepengurusan masjid.Dengan demikian tanpa perencanaan yang baik, tidak hanya membuat kepengurusan dan aktifitas menjadi kacau dan tidak punya arah yang jelas, tetapi kemajuan dan kemunduran juga tidak bisa diukur.Akhirnya, jamaah masjid hanya beraktifitas secara rutin karena memang sudah menjadi kewajiban yang harus 
digugurkan tanpa ada upaya meningkatkan kuantitas dan kualitasnya.

\section{Organizing}

Pengorganisasian dalam manajemen masjid adalah penyatuan, pengelompokan dan pengaturan pengurus masjid untuk digerakkan dalam satu kesatuan kerja yang telah direncanakan. Pengorganisasian sangat penting bagi proses jalannya suatu kagiatan yang akan dilaksanakan dan telahdirencanakan sebelumnya. Masjid Istiqamah dalam melaksanakan program sebelumnya dilakukan pengorganisasian.Hal ini dilaksanakan agar nanti dalam melaksanakan programprogramnya tidak terjadi benturan-benturan psikologi dikalangan para pengurus masjid dan tidak terjadi tumpang tindih dalam pengawasan tugas.Dengan pengorganisasian maka rencana kegiatan menjadi lebih mudah dalam pelaksanaannya, dan sekaligus adanya pembagian kegiatan-kegiatan dan tugas kepada pelaksananya sehingga mempermudah pendistribusian pada pelaksanaannya.

Di Masjid Istiqamah pengorganisasian diterapkan pada pengurus atau takmir masjid, muadzin, remaja masjid, bimbingan haji dan umroh serta pengurus Masjid Istiqamah tentang pembagian tugas yang harus dilaksanakan oleh para pengurus masjid. Tugas yang diberikan kepada masing-masing pengurus memudahkan dalam melaksanakan kegiatan sehingga akan lebih terarah. Pengorganisasian di Masjid Istiqamah diadakan bersamaan dengan penyusunan struktur kepengurusan masjid.

Didalam rapat ini dibentuklah struktur kepengurusan masjid dan ditetapkannya pula bagian-bagian tugas dan tanggung jawabnya menjadi pengurus atautakmir masjid. Selain itu pengorganisasian di masjid juga ditetapkan untukmenentukan imam-imam dan khotib-khotib sehingga apabila Imam ataukhotibberhalangan maka tugasnya dapat di gantikan oleh imam atau khotib lainnya.

Dari pemaparan di atas dapat penulis analisis setelah melihat hasil dilapangan, bahwa pengorganisasian di Masjid Istiqamah telah terencana dengan baik karena telah menempuh langkah-langkah: 1) Membagi dan menggolongkan tindakan-tindakan dalam kesatuan-kesatuantertentu. Seperti telah dibagi dan digolongkan tugas dari masing-masing dewan yang ada di struktur Masjid Istiqamah. 2) Menetapkan dan merumuskan tugas dari masing-masing kesatuan sertamenempatkan pelaksana untuk melaksanakan tugasnya. Selain memilih menjadibeberapa dewan pihak pengurus atau takmir juga menentukan tugas yang harusdilaksanakan oleh masing-masing dewan dan seksi-seksi. 3) Memberikan wewenang kepada para pelaksana .ketua umum juga memberikanwewenang kepada para pelaksana agar tugas yang diembannya dapat berjalandengan baik dan berhasil. 4) Menetapkan jalinan hubugan. Dalam menjalankan programnya pihak 
masjid jugamengadakan kerjasama baik dengan pemerintah para alim ulama maupunmasyarakat sekitar masjid.

Sedangkan untuk mencapai pengorganisasian yang efesien Masjid Istiqamah melakukan langkah-lagkah yang sistematis yaitu : 1) Ketahui terlebih dahulu sasaran dari pengorganisasian dalam sitiasi lingkungan. 2) Bagilah pekerjaan yang harus dilaksanakan kedalam aktifitas-aktifitas bagian. 3) Kelompokanlah aktivitasaktivitas tersebut kedalam kesatuan praktis yangdidasarkan atas persamaan pentingnya aktifitas atau pihak mana yang akanmelaksanakan pekerjaan tersebut. 4) Tetapkanlah tugas-tugas dan sediakanlah alat-alat fisik bagi masingmasingaktivitas ataupun kelompok aktivitas. 5) Tugaskanlah personil yang kompeten atau potensial dan dapat di kembangkan. 6) Beritahukanlah pada masing-masing anggota, aktivitas apa yang diharapkan akandilaksanakan dan hubungannya dengan pihak lain yang bersangkutan.

Langkah-langkah tersebut di tempuh dalam rangka pengorganisasian, maka tersusunlah pola atau bentuk kerjasama itu dan mengetahui pekerjaan apa yang harus dilaksanakan, sampai sejauhmana wewenang masing-masing serta jalinan hubungan antara satu dengan yang lain dalam rangka usaha kerjasama tersebut. Dalam pengorganisasian juga terdapat proses komunikasi antara ketua pengurus dengan anggota pengurus masjid, dengan menerapkan langkah-langkah operasional dalam usaha mencapai tujuan dan pemakmuran masjid.

Menurut analisa penulis, terlaksananya pengorganisasian yang efisien memiliki arti yang sangat penting, sebab dalam pelasanaannya akan mempermudah penugasan kepada staf pengurus, karena sudah jelas seksi apa dan siapa yang harus melaksanakan suatu bidang tegiatan, memudahkan dipilihnya tenaga pelaksana yang tepat, karena dalam pengorganisasian bukan hanya menyusun struktur dan menempatkan orangnya, tetapi juga menguraikan tugas dan tanggung-jawabnya sehingga bisa dipilih siapa yang tepat unuk menempati posisi suatu kepengurusan. Pengorganisasian juga akan membuat terpadunya berbagai potensi pengurus dan suatu kerangka kerjasama pemakmuran masjid serta dengan pengorganisasian juga akan memudahkan bagi pemimpin untuk mengendalikan dan mengevaluasi pelaksanaan suatu kegiatan.

\section{Actuating}

Penggerakan dalam manajemen takmir masjid memiliki arti yang sangat penting, sebab penggerakan memliki arti lebih dibandingkan dengan fungsi manajemen lainnya.Maka penggerakan merupakan fungsi yang secara langsung berhubungan erat dengan manusia.Penggerakan dilakukan oleh seorang pemimpin yang menjadi penentu bagi suksesnya sebuah pelaksanaan tugas. Oleh karena itu pemimpin harus melibatkan seluruh pengurus dalam melaksanakan tugas, membukajalur komunikasi yang seluas luasnya diantara sesama pengurus masjid, baik melalui 
rapat, membuat nota dan menelepon.Selain itu pemimpin juga harus selalu meningkatkan kemampuan kerja stafnya dan memberikan penghargaan atas prestasi yang dicapai oleh stafnya.

Setiap program dan kegiatan yang dilaksanakan tentu tidak akan berjalan dengan baik dan teratur jika tidak ada proses penggerakan. Dalam hal ini membutuhkan kerja keras dari pemimpin dan kepengurusan masjid menjadi penentu bagi suksesnya suatu pelaksanaan kegiatan, karena itu pemimpin harus melibatkan seluruh pengurus dalam pelaksanan tugas yaitu dengan membuka jalur komunikasi yang seluas-luasnya diantara sesama pengurus.Seorang pemimpin harus memberikan rangsangan atau motivasi kepada pengurus untuk melaksanakan tugas dan tanggung-jawabnya.Karena itu pemimpin perlu memberikan motivasi, bimbingan danmengarahkan staf pengurus masjid guna menunaikan amanah kepengurusan dengan baik.

Fungsi penggerakan yang dilakukan oleh takmir Masjid Istiqamah dalam melaksanakan program-programnya, salah-satunya seperti penggerakan program bimbingan haji dan umroh, dalam hal ini Masjid Istiqamah memberikan bimbingan dan tuntunan kepada calon jamaah haji.Selain itu juga sering diadakan pengajian-pengajian dengan berbagi tema tentang pengetahuan manasik haji dan umroh.

Berdasarkan data diatas dan hasil wawancara dengan Ketua Bidang Kemasjidan dan Dakwah maka dapat penulis analisis, bahwa fungsi penggerakan manajemen takmir Masjid Istiqamah telah berjalan dengan baik karena dengan melakukan fungsi penggerakan, Masjid Istiqamah telah menempuh langkahlangkah penggerakan sebagai berikut: 1) Pemberian Motivasi, pemimpin dan pengurus masjid memberikan motivasi kepada jamaah dan masyarakat. 2) Pembimbingan, pihak masjid juga memberikan bimbingan kepada jamaah melalui pengajian-pengajian rutin dan melalui lembaga-lembaga kemaslahatan keluarga dan penasehat perkawinan yang dibentuk oleh Masjid Istiqamah. 3) Penjalinan Hubungan, dalam melaksanakan programnya pihak masjid menjalin hubungan kerjasamadenagan pihak-pihak luar. Penggerakan Komunikasi, pimpinan dan pengurus masjid melakukan penggerakan komunikasi ini melaluisegala kegiatan yang ada di Masjid Istiqamah. 4) Pengembangan dan Peningkatan Pelaksana, pimpinan dan pengurus masjid mengembangkan dan meningkatkan programkesehatan masyarakat dengan pengobatan gratis pada jamaah dan masyarakat sekitar.

Penggerakan merupakan fungsi yang sangat penting, bahkan menentukan jalannya proses pelaksanaan kegiatan masjid, sehingga dapat dikatakan bahwa penggerakan itu merupakan inti dari manajemen masjid. Proses menggerakan pengurus atau jamaah untuk melakukan aktifitas dan kegiatan program masjid, akan membantu tercapainya tujuan atau sasaran penggerakan. Penggerakan 
bermaksud meminta pengorbanan para pelaksana untuk melakukan kegiatan yang telah ditugaskan.Hal ini hanya mungkin bilamana pimpinan mampu memberikan motivasi, membimbing, mengkoordinir dan menjalin pengertian diantara mereka serta selalu meningkatkan kemampuan dan keahlian mereka. Fungsi penggerakan ini dilakukan oleh pemimpin pengurus Masjid Istiqamah ketika diadakan rapat rutin dan rapat ketika akan diadakannya kegiatan yang melibatkan para staf dan pengurus.

\section{Controlling}

Pengawasan adalah tindakan mengkaji apakah kegiatan-kegiatan yang dilakukan para anggota kelompok sesuai dengan rencana yang telah ditetapkan.Namun, kata "Pengawasan" sering mempunyai konotasi yang tidak menyenangkan karena dianggap akan mengancam kebebasan otonomi pribadi. Padahal organisasi sangat memerlukan pengawasan untuk menjamin tercapainya tujuan.Pengawasan ini perlu dilaksanakan untuk memperoleh kepastian bahwa pekerjaan yang dilakukan oleh para anggota kelompok selaras dengan tujuan yang telah ditetapkan.Pengawasan dalam manajemen masjid sangat diperlukan.Bukan saja untuk menapai tujuan organisasi tetapi juga untuk menciptakan keyakinan yang kental dari masyarakat terhadap pengelolaan kekayaan dan harta masjid.Sehingga masyarakat lebih yakin dan memberikan kepercayaannya kepada masjid. Terlaksananya fungsi ini akan membuat semua pengurus tahu akan adanya kesalahan kekurangan, rintangan, tantangan dan kegagalan dalam mencapai tujuan pemakmuran masjid.

Pengawasan dapat dilakukan dengan mengambil jalannya pelaksanaan kegiatan masjid, mengukur keberhasilan dan kegagalannya dengan standar sebagaimana yang telah di tetapkan dalam perencanaan.Untuk selanjutnya memperbaiki kesalahan dan kekurangan serta mencegah terjadinya kegagalan.Fungsi pengawasan ini dilaksanakan oleh pengurus Masjid Istiqamah ketika telah melaksanakan kegiatan, maka pimpinan dan seluruh staf takmir masjid selalu mengadakan evaluasi terhadap jalannya kegiatan yang telah dilakukan, apakah lebih baik dari sebelumnya atau malah sebaliknya.Yaitu dengan memberikan laporan kepada setiap pengurus yang telah mendapatkan tugas.

Hal ini dilakukan tidak hanya setiap telah melakukan kegiatan melainkan dilaksanakan pada setiap program dan menurut analisis penulis, fungsi pengawasan yang diterapkan takmir Masjid Istiqamah cukup baik dan efesien, sehingga ini akan memberikan kepecayaan donatur dan jamaah serta meningkatnya peran dan fungsi masjid.

Masjid Istiqamah melakukan pengawasan dan penilaian.Dimaksudkan agar pemimpin dapat mengambil tindakan pencegahan tindakan terhadap kemungkinan terjadinya penyimpangan dan kekurangan yang ada. Sehingga akan 
dapat mengurangi kesalahan yang sedang berlangsung. Disamping itu dapat dapat melakukan usaha-usaha peningkatan penyempurnnaan sehingga proses pelaksanaan kegiatan tidak berhenti. Melainkan semakin meningkat dan sempurna. Penerapan fungsi manajemen masjid akan menjadikan masjid dalam menciptakan suasana keagamaan yang terorganisir, sehingga akan berjalan dengan baik sesuai dengan apa yang diharapkan.

. Dalam menyelenggarakan berbagai kegiatan di Masjid Istiqamah guna meningkatnya peran dan fungsi masjid tidaklah semudah dan selancar yang diharapkan, ada beberapa faktor hambatan dan tantangan dalam pelaksanaan kegiatan masjid. Adapun yang menjadi faktor penghambat antara lain; Kurang solidnya kepengurusan masjid; Kurangnya partisipasi remaja masjid; Kurang keterlibatannya jamaah

Selain adanya hambatan bagi pelaksanaan manajemen masjid ada juga tantangan yang harus dihadapi antara lain; masyarakat di sekitar Masjid Istiqamah yang cenderung individualis, sehingga berakibat pada kurangnya konsolidasi antara pengurus dengan masyarakat sekitar dan menyebabkan sedikitnya jamaah yang tinggal di sekitar Masjid Istiqamah untuk turut hadir pada kegiatan yang dilaksanakan.

Secara umum strategi adalah konsep dan kerangka berfikir. Dalam konteks organisasi secara keseluruhan, strategi dideskrifsikan sebagai suatu cara dimana organisasi akan mencapai tujuan-tujuannya. Sesuai dengan peluang-peluang dan ancaman-ancaman lingkungan eksternal yang dihadapi serta sumber daya dan kemampuan internal organisasi. Berdasarkan definisi tersebut terdapat tiga faktor yang mempunyai pengaruh penting pada strategi yaitu lingkungan eksternal, sumber daya dan kemampuan internal. Serta tujuan yang ingin dicapai.

Pada intinya suatu strategi organisasi memberikan dasar-dasar pemahaman tentang bagaimana organisasi itu akan bersaing dan survive. Strategi ini dalam segala hal digunakan untuk mencapai tujuan yang telah ditetapkan. Tujuan tidak mudah dicapai tanpa strategi, karena pada dasarnya segala tindakan atau perbuatan itu terlepas dari strategi. Adapun mengenai taktik,sebenarnya merupakan cara yang digunakan dan merupakan bagian dari strategi. Strategi yang terdapat dalam suatu lembaga atau organisasi tidak bisa dipungkiri lagi jika dilihat dari realitas yang ada, maka strategi dapat diartikan sebagaitarget atau tujuan yang ingin dicapai, yang ingin diberdayakan dalam upaya pengembangan Masjid Istiqamah.

Dengan adanya strategi maka usaha untuk mengoptimalkan peran dan fungsi Masjid Istiqamah akan semakin mudah. Strategi yang dilakukan oleh Masjid Istiqamah menurut pengamatan penulis yaitu, bahwa Masjid Istiqamah selalu berusaha menjalankan segala kegiatan dengan mengoptimalkan fungsi-fungsi manajemen yang diterapkan serta selalu mengadakan evaluasi rutin dalam rangka membenahi segala bentuk kekurangan yang terjadi baik dalam bentuk kegiatan 
maupun kepengurusan, Masjid Istiqamah pun memanfaatkan semua media sosial yang ada, misalya pemanfaatan grup pada seluler, untuk memudahkan komunikasi dengan jama'ah, pembutan blog resmi Yayasan Istiqamah, untuk informasi seputar yayasan termasuk didalamnya masjid dan dakwah.

\section{PENUTUP}

Setelah penulis mengadakan penelitian terhadap optimalisasi fungsi manajemen dalam meningkatkan peran dan fungsi masjid pada Masjid Istiqamah Bandung, dan berdasarkan yang telah penulis uraikan dari hasil penelitian tersebut, maka menulis mengambil kesimpulan sebagai berikut : 1) Penerapan fungsi perencanaan pada setiap kegiatan dan program yang meliputi peramalan, penentuan sasaran, penjadwalan, pengganggaran dan penentuan prosedur kerja mendukung tercapainya misi dan tujuan yang telah disepakati. 2) Penerapan fungsi pengorganisasian pada Masjid Istiqamah yang meliputi pengorganisasian alat, pengelompokan kerja, penentuan dan pelimpahan tanggung jawab dan wewenang serta pengaturan hubungan kerja menghasilkan kerja-sama yang baik antara pengurus pusat Yayasan Istiqamah dengan Pengurus Masjid. 3) Penerapan fungsi penggerakan pada Masjid Istiqamah yang meliputi pimpinan memberikan motivasi dan mengkoordinasi sehingga menghasilkan konsistensi pada masingmasing pengurus. 4) Penerapan fungsi pengendalian pada Masjid Istiqamah yang meliputi pemimpin melakukan penilaian dan evaluasi pada setiap kegiatan maupun kepengurusan.

Setelah penulis mengadakan penelitian dan menganalisa data yang berhubungan dengan berbagai hal manajemen takmir Masjid Istiqamah, maka ada beberapa saran yang akan penulis sampaikan: 1) Perencanaan yang diterapkan dalam berbagai kegiatan dan kepengurusan diharapkan lebih sistematis dan flexible agar usaha-usaha perencanaan yang bersifat formal tidak menciptakan sebuah kekakuan dalam berorganisasi dan mengunci sasaran-sasaran tertentu yang harus dicapai dalam batas waktu tertentu. 2) Pengorganisasian harus lebih inovatif agar kegiatan-kegiatan dakwah dapat terlaksana secara logis dan sistematis.

Diharapkan organisasi tidak terjebak dalam sebuah standarisasi kerja, karena standarisasi bukan saja memungkinkan para da’i untuk terlibat dalam tindakan alternatif, tetapi standarisasi juga akan memandulkan peran da'i untuk memikirkan alternatif. Karena dalam organisasi dakwah, da'i sering kali dituntut untuk banyak melakukan improvisasi dalam pekerjaan atau tugas-tugasnya. 3) Lebih mengoptimalkan fungsi penggerakan seperti memberikan penjelasan kepada semua unsur organisasi secara komprehensif mengenai hal-hal manajemen agar setiap anggota organisasi menyadari, memahami, dan menerima dengan baik proses atau tujuan yang telah ditetapkan. Karena penggerakan merupakan inti dari 
manajemen dakwah dan dalam proses ini semua aktivitas dakwah dilaksanakan. 4) Fungsi controlling harus dikonsentrasikan pada pelaksanaan aktivitas tugas-tugas yang sedang berlangsung maupun yang telah selesai dilakukan. Hal ini dimaksudkan sebagai upaya preventif terhadap kemungkinan-kemungkinan terjadinya penyimpangan serta upaya peningkatan dan penyempurnaan terhadap sebuah proses ke depan.

\section{DAFTAR PUTAKA}

Ayyub M, (1996). Manajemen Masjid. Jakarta: Gema Insani Press.

Fatah N. (2000). Landasan Manajemen Pendidikan. Bandung: Rosda.

FIDKOM. (2007). Panduan Penyusunan Skripsi Dakwah dan Komunikasi. Bandung: FIDKOM Bandung.

Gitosudarmo I. (1996). Prinsip-prinsip Dasar Manajemen. Yogyakarta: BPFE.

Handoko T. (2004). Manajemen. BPFE edisi $2^{\text {nd }}$; Yogyakarta.

Hasibuan M. (2006). Manajemen Dasar Pengertian dan Masalah. Jakarta: Bumi Aksara Jalaluddin R. (1982). Retorika Modern, Sebuah Kerangka Teori dan Praktik. Berpidato. Bandung: Akademika.

KEMENAG RI, (2009). Al-Qur'an Terjemah. Bandung: Fitrah Rabbani.

Moleong L. (2010). Metode Penelitian Kualitatif. Bandung: Rosdakarya.

Munawir A, (1984). AL-Munawir, Kamus bahasa Arab-Indonesia. Yogyakarta: PP. AlMunawir Krapyak.

Munir M. \& Wahyu Ilaihi. (2006). Manajemen Dakwah. Jakarta: Kencana

Mustofa B. (2008). Manajemen Masjid. Surakarta: Ziyad Visi Media;

Rifa’i B \& Moch. Fakhruroji. (2005). Manajemen Masjid, Mengoptimalkan Fungsi Sosial-Ekonomi Masjid. Bandung: Benang Merah Press.

Siagian S. (1996). Manajemen Sumber Daya Manusia. Jakarta: Ghalia Indonesia. (2007). Fungsi-fungsi Manajerial. Jakarta: PT.Bumi Aksara.

Supardi \& Teuku Aminudin. (2001). Manajemen Masjid dalam Perkembangan Masyarakat, Jakarta: UII Press.

Terry George, (2009). Prinsip-prinsip Manajemen. Jakarta: Bumi Aksara.

Tunggal A W. (1993). Manajemen, Suatu Pengantar, Jakarta: PT. Rineka Hasan.

Wursanto. (1987). Pokok-pokok Perencanaan. Yogyakarta: Kanisius.

Yani A. (1999). Panduan Memakmurkan Masjid. Jakarta: Dea Press. 
M.R. Taufiq $\mathbf{H}$ 